\title{
An empirical evaluation of the normative justifications for cartel criminalisation
}

\begin{abstract}
Andreas Stephan*
University of East Anglia

A growing number of jurisdictions treat 'hardcore' cartel conduct as crime, in the belief that the threat of incarceration is necessary for deterrence. The significant economic harm caused by cartels is generally undisputed, but there is disagreement over whether cartel conduct is morally offensive enough to justify criminalisation. Critics argue that it is another example of 'over-criminalisation', seeking to regulate an activity that is morally ambiguous. Those in favour have sought to formulate normative justifications for why cartel conduct should be crime. Many of these rely on the assumption that members of society expect markets to be competitive and believe cartels are undesirable. This paper makes a significant contribution by testing this question empirically. Public surveys from the UK, Germany, Italy and the US are used to critically analyse the extent to which normative justifications for cartel conduct have empirical backing.
\end{abstract}

Andreas Stephan, UEA Law School and Centre for Competition Policy, University of East Anglia, Norwich NR4 7TJ, UK. Email: a.stephan@uea.ac.uk

\section{INTRODUCTION}

This paper makes the first empirical contribution to the question of whether cartel conduct between competing firms should be subject to criminal sanctions. Cartel criminalisation has been entirely justified on deterrence grounds and has not come about as a result of popular concern at the harmful effects of anti-competitive conduct. Critics argue that it is an example of the criminal law being misused to prohibit conduct that is morally ambiguous. Scholars have responded to this by formulating normative justifications for cartel criminalisation, which broadly rely on the assumption that members of society expect markets to be competitive and understand that cartel conduct is harmful. This contribution tests the robustness of this assumption by analysing the results of four public surveys carried out in the UK, Germany, Italy and the US.

Cartel conduct refers to anti-competitive arrangements between competing firms that restrict or prevent competition. These can involve price fixing, bid-rigging in tendering, the restriction of output, and the sharing or dividing of customers and geographical markets. It is generally accepted that such conduct is harmful to consumers and the wider economy, resulting in less being sold at higher prices than would otherwise be the case. ${ }^{1}$ In its most damaging form, cartel conduct does not only have a monetary cost.

* The support of the Economic and Social Research Council (UK) is gratefully acknowledged. The usual disclaimer applies.

1. See OECD 'Recommendation of the Council concerning effective action against hard core cartels' C(98)35/FINAL (May 1998). 
The combination of higher prices and lower output will mean that many consumers can no longer afford the product or service in question. As cartels tend to form around essential goods for which there are few substitutes, this can have a real adverse effect on individuals' standard of living. ${ }^{2}$ Indeed, a recent report by the World Bank has suggested that if the price of food staples were reduced by $10 \%$ through better tackling of cartels, it could lift 500,000 people in Kenya, South Africa and Zambia out of poverty and save consumers there US\$700 million a year. ${ }^{3}$ It is hard to accurately estimate the global cost of cartel behaviour, but just the arrangements that are detected affect markets worth tens of billions of US dollars ${ }^{4}$ and these arrangements are thought, on average, to increase prices by between $16 \%$ and $20 \% .^{5}$

Historically, cartels were treated with ambivalence and even encouraged during periods of economic instability, ${ }^{6}$ but since the 1950 s there has been a growing recognition of the harm they cause. Today, around 130 jurisdictions have some form of cartel prohibition, many spurred on by the US, the EU and international bodies such as the IMF and World Bank. ${ }^{7}$ Most have followed the EU model of a purely civil or administrative enforcement regime, in which the only sanction is a corporate fine of up to $10 \%$ of an undertaking's worldwide turnover. In the EU, these have been increasing exponentially since the 1990 s, with a record fine of $€ 2.93$ billion imposed on five manufacturers of trucks in July $2016 .{ }^{8}$ As confirmed by the European Court

2. UNCTAD 'The impact of cartels on the poor' (24 July 2013), available at http://unctad.org/ meetings/en/SessionalDocuments/ciclpd24rev1_en.pdf (accessed 20 December 2016).

3. World Bank Breaking Down Barriers: Unlocking Africa's Potential Through Vigorous Competition Policy (June 2016), available at http://documents.worldbank.org/curated/en/ 243171467232051787/pdf/106717-REVISED-PUBLIC-Africa-Competition-Report-FINAL. pdf (accessed 20 December 2016), at iii.

4. For example, the US Department of Justice estimated that in the period 1997-2000, just the international cartels that were detected and prosecuted affected in excess of US\$10 billion in US commerce. Some of these achieved price increases as great as $70 \%$ during some periods of their duration. See JM Griffin, speech at Criminal Practice and Procedure Committee, American Bar Association Section of Antitrust Law, 49th Annual Spring Meeting, Washington, DC (28 March 2001), available at https://www.justice.gov/atr/speech/criminal-cartel-enforcement-statusreports (accessed 20 December 2016).

5. JM Connor and Y Bolotova 'Cartel overcharges: survey and meta-analysis' (March 2005), available at http://papers.ssrn.com/sol3/papers.cfm?abstract_id=788884 (accessed 20 December 2016); OECD 'Hard core cartels - harm and effective sanctions', Policy Brief (May 2002), available at http://www.oecd.org/competition/cartels/21552797.pdf (accessed 20 December 2016); M Boyer and R Kotchoni 'The econometrics of cartel overcharges' (2011) Montreal Scientific Series, available at https://www.cirano.qc.ca/pdf/publication/2011s-35.pdf (accessed 20 December 2016).

6. For a discussion of the historical treatment of cartels and the influence of the US, see C Harding and J Joshua Regulating Cartels in Europe (Oxford: Oxford University Press, 2nd edn, 2010), ss I, II. Even in the US, the US National Industry Recovery Act 1933 effectively legalised cartels in the wake of the Great Depression, but has since been shown to have prolonged economic recovery rather than achieving its stated aim of promoting stability. See HL Cole and LE Ohanian 'New Deal policies and the persistence of the Great Depression: a general equilibrium analysis' (2004) 112(4) J Pol Econ 779-816.

7. See DD Sokol and A Stephan 'Prioritizing cartel enforcement in developing world competition agencies' in DD Sokol, TK Cheng and I Lianos (eds) Competition Law and Development (Stanford, CA: Stanford University Press, 2013).

8. European Commission - press release 'Antitrust: Commission fines truck producers $€ 2.93$ billion for participating in a cartel’ (19 July 2016) IP/16/2582. 
of Human Rights, cartel fines are unmistakably punitive in character. Their purpose is to punish and deter, not to simply regulate the way in which firms interact with each other. ${ }^{9}$ Yet these fines are imposed directly by the European Commission in a process that allows it to act as investigator, prosecutor, judge and jury. There is no true independent adjudication before appeal. ${ }^{10}$

For many years, the US was the only active criminal cartel enforcement regime in the world. Cartels were first prohibited under the US Sherman Act 1890 and became a felony in 1974. The US Department of Justice regularly secures convictions of firms and individuals - many of whom agree to serve custodial sentences under negotiated plea agreements ${ }^{11}$ - from around the world. In the past 20 years, there has been a movement, internationally, towards the US model. Around 25 jurisdictions have criminalised 'hardcore' cartel conduct, including the UK, France, Ireland and Australia - with many more having criminal offences that relate only to bid-rigging in public procurement. ${ }^{12}$ Most of these have chosen to retain their civil enforcement powers in parallel, so as to use criminal enforcement selectively. Within the EU, a divergence has emerged, in that some Member States have adopted criminal offences while others have chosen to reject them. It appears that the decision to reject criminalisation has been primarily motivated by practical concerns, rather than worries relating to legitimacy or questions of morality. Sweden and Finland, for example, both felt that it would jeopardise the effectiveness of their enforcement regimes by undermining leniency programmes. ${ }^{13}$ Although there is clear momentum behind the cartel criminalisation movement, the actual use of criminal cartel offences outside the US is still in its infancy, with only a small number of convictions and even fewer custodial sentences. ${ }^{14}$

9. See eg J Almunia (Vice President of the European Commission responsible for Competition Policy) 'Fighting against cartels: a priority for the present and for the future', speech, Brussels (3 April 2014), available at http://europa.eu/rapid/press-release_SPEECH-14-281_en.htm (accessed 20 December 2016); Office of Fair Trading (OFT) Cartels and the Competition Act 1998 (2005) OFT435: '.. not only will members of the cartel be penalised, but a very strong deterrent message will be sent to other businesses that may be contemplating cartel activity' ( $\mathrm{p}$ 10).

10. Stenuit v France [1992] ECC 401, Case C-272/09P; Engel v Netherlands (1979-80) 1 EHRR 647.

11. DI Baker 'Punishment for cartel participants in the US: a special model?' in C Beaton-Wells and A Ezrachi (eds) Criminalising Cartels: Critical Studies of an International Regulatory Movement (Oxford: Hart Publishing, 2011).

12. See eg F Wagner-von Papp 'What if all bid riggers went to prison and nobody noticed? Criminal antitrust law enforcement in Germany' in Beaton-Wells and Ezrachi, above n 11.

13. See OECD Annual Report on Competition Policy Developments in Finland (16-18 June 2015), available at http://www.oecd.org/officialdocuments/publicdisplaydocumentpdf/? cote $=\mathrm{DAF} / \mathrm{COMP} / \mathrm{AR}(2015) 14 \&$ docLanguage $=$ En (accessed 20 December 2016). Leniency is a defining characteristic of modern cartel enforcement. Immunity from fines is offered to the first firm to self-report an infringement. Around two thirds of cartels in Europe are uncovered thanks to this tool.

14. Ireland is probably the most successful of these, although no prosecutions there have yet resulted in a custodial sentence: T Calvani and KM Carl 'The Competition Act 2002, ten years later: lessons from the Irish experience of prosecuting cartels as criminal offences' (2013) 1(2) J Antitrust Enforcement 296; also see generally M Furse The Criminal Law of Competition in the UK and in the US (Cheltenham: Edward Elgar, 2012). 
From the information available, it would appear that criminalisation in these jurisdictions was motivated entirely by deterrence arguments and the prevention of economic harm, ${ }^{15}$ in particular, the desire to impose effective punishment on individuals, in addition to corporate fines against the firm. For example, in the UK it was thought that 'the threat of a criminal conviction and the possibility of a prison sentence means that individuals are more likely to think very carefully before engaging in cartels'. ${ }^{16}$ This was later supported by an empirical study for the Office of Fair Trading (OFT) in 2010 (now the Competition and Markets Authority, or CMA), which found that the deterrent effect of threatened criminal penalties was significantly greater than fines. ${ }^{17}$ In $_{\text {Ireland }}{ }^{18}$ and Australia ${ }^{19}$ too, criminalisation was driven by deterrence arguments that civil penalties were not strong enough to deter and did not impact sufficiently on individual decision makers responsible for cartel arrangements. As if to endorse this justification, when Ireland received a 'Programme of Financial support' from the EU and the IMF in 2010, in the wake of the financial crisis, it included a requirement that fines and other competition law sanctions be reformed 'to generate more credible deterrence'. ${ }^{20}$ This resulted in the Irish government doubling their maximum sentence to 10 years under the Competition [Amendment] Act 2012. There is no evidence to suggest that cartel criminalisation is being driven by any kind of surge in popular outrage or moral opprobrium associated with the act of forming a cartel. Indeed, even in the US, where arguably there was popular support for the Sherman Act, cartel laws have not historically been seen as 'crimes of moral turpitude'. ${ }^{21}$ Competition authorities do occasionally draw vague parallels between

15. See A Stephan 'How dishonesty killed the cartel offence' (2011) 6 Crim L Rev 446-455. 16. Department of Trade and Industry (DTI) White Paper A World Class Competition Regime (CM 5233) 2001, para 7.33; see also Joint Treasury/DTI Report The UK's Competition Regime (2001); OFT 'Proposed criminalization of cartels in the UK', a report prepared for the OFT by Sir Anthony Hammond KCB QC and Roy Penrose OBE QPM (November 2001) 1.4.

17. OFT Drivers of Compliance and Non-compliance with Competition Law: An OFT Report (May 2010) OFT 1227.

18. Criminal sanctions were introduced by the Competition Act 1996, with important reforms made under the Competition Act 2002. For a discussion of why Ireland criminalised and the background, see P Massey and JD Cooke 'Competition offences in Ireland: the regime and its results' in Beaton-Wells and Ezrachi, above n 11, ch 5.

19. This was originally recommended by the Australian Competition and Consumer Commission: ACCC 'Submission to the Trade Practices Act Review (Public Submission No 50, 2002) 35. It persuaded the Dawson Committee to recommend criminalisation: Trade Practices Act Review Committee Review of the Competition Provisions of the Trade Practices Act (Commonwealth of Australia, Canberra, report dated 31 January 2003, released 16 April 2003). For discussion, see C Beaton-Wells and B Fisse 'Criminalising serious cartel conduct: issues of law and policy' (2008) 36 Austral Bus L Rev 166.

20. EU/IMF Programme of Financial Support for Ireland (16 December 2010); A Stephan 'Will IMF requirement that Ireland strengthen competition law sanctions actually make a difference? Competition Policy Blog (31 October 2011), available at https://competitionpolicy. wordpress.com/ (accessed 20 December 2016).

21. J Flynn 'Criminal sanctions under state and federal antitrust laws' (1967) 45 Tex L Rev 1301 at 1315, discussed by GJ Werden 'Sanctioning cartel activity: let the punishment fit the crime' (2009) 5(1) Eur Competition J 19. 
cartel conduct and theft or fraud, but these largely arise in the context of public relations and occur regardless of whether the enforcement process is criminal or civil. $^{22}$

The deterrence argument at the heart of cartel criminalisation is generally drawn from modern economic theory. ${ }^{23}$ It assumes that businesses make rational choices about whether to break the law and will only engage in cartel behaviour where it is profitable to do so. It is thought that corporate fines alone cannot achieve this. The problem is that fines are typically imposed on undertakings some years after the cartel was formed and are unlikely to directly impact on the individuals responsible. ${ }^{24}$ It is also questionable whether fines are capable of outweighing illegal cartel profits without making firms insolvent. $^{25}$ To illustrate this point, between January 2006 and December 2015, the European Commission imposed fines averaging around $2.2 \%$ of infringing firms' annual worldwide turnover. ${ }^{26}$ Yet empirical estimates of average overcharges achieved by cartels range from $16 \%$ to $20 \%$ and are thought to be as high as $60 \%$ for some international cartels. ${ }^{27}$ In addition, this does not allow for the fact that cartels average around 7 years in duration and that the rate of detection may be as low as $13 \%$ of cartels

22. Examples of this include Klein's famous observation that cartels amount to 'theft by well dressed thieves'; JI Klein 'The war against international cartels: lessons from the battlefront', speech at Fordham Corporate Law Institute (14 October 1999); and the New York and the US Supreme Court's description of cartels as 'the supreme evil of Antitrust' Verizon Communications $v$ Law Offices of Curtis v Trinko (2004) 540 US 398, 408. Some have noted an assumption by the ACCC that members of the public saw cartels as equivalent to theft, although there was no clear evidence of this at the time. See C Beaton-Wells and C Parker 'Justifying criminal sanctions for cartel conduct: a hard case' (2013) 1(1) J Antitrust Enforcement 198; C Beaton-Wells and F Haines 'Making cartel conduct criminal: a case study of ambiguity in controlling business behaviour' (2009) 42(2) Austral \& NZ J Crim 218.

23. The economic paradigm of deterrence was expressed in the seminal article: G Becker 'Crime and punishment: an economic approach' (1968) 76 J Pol Econ 169.

24. OECD Cartels: Sanctions Against Individuals (Paris: OECD Competition Committee, 2003).

25. A Stephan 'The bankruptcy wildcard in cartel cases' (August 2006) J Bus L 511-534.

26. This figure includes immunity applicants, whose fine was zero, but who nevertheless were involved in the cartel and were subject to an infringement decision. The data is taken from statistics published on the website of the European Commission: http://ec.europa.eu/ competition/cartels/statistics/statistics.pdf (accessed 20 December 2016).

27. JM Connor and RH Lande 'Cartel overcharges and optimal cartel fines' in Issues in Competition Law and Policy vol 3 (Chicago: ABA Section of Antitrust Law, 2008) ch 88, pp 2203-2218; JM Connor 'Price fixing overcharges: revised 3rd edition', unpublished manuscript (February 2014), available at http://papers.ssrn.com/sol3/papers.cfm?abstract_id=2400780 (accessed 20 December 2016); F Smuda 'Cartel overcharges and the deterrent effect of EU competition law' ZEW Discussion Paper no 12-050 (July 2012), available at ftp://ftp.zew.de/ pub/zew-docs/dp/dp12050.pdf (accessed 20 December 2016); Y Bolotova 'Cartel overcharges: an empirical analysis' (2006) unpublished manuscript, available at http://papers.ssrn.com/sol3/ papers.cfm?abstract_id=931211 (accessed 20 December 2016); Y Bolotova, JM Connor and DJ Miller 'Factors influencing the magnitude of cartel overcharges: an empirical analysis of the US market' (2009) 5(2) J Competition L \& Econ 361-381; M Boyer and R Kotchoni 'How much do cartels overcharge?' (2015) 47(2) Rev Industrial Org 119-153; OECD Hard Core Cartels (Paris: OECD, 2000), available at http://www.oecd.org/competition/cartels/2752129.pdf (accessed 20 December 2016). 
formed. ${ }^{28}$ Under deterrence theory, fines would need to be multiplied to compensate for these factors. As civil fines imposed on individuals can be indemnified by the firm or taken into account when weighing up the potential benefits and costs of colluding, it is thought that only the threat of gaol can pose a truly deterrent effect.

Against this backdrop, a lively debate has emerged on whether it is justifiable for 'hardcore' cartel conduct to be treated as crime. While few would dispute the social harm caused by cartels, the deterrence arguments outlined above do not address the question of whether cartel conduct is of sufficient moral opprobrium to be treated as crime. Drawing on the wider literature on 'over-criminalisation', ${ }^{29}$ Jones and Williams point to the morally ambiguous nature of cartel conduct and the lack of any bottom-up moral outrage, to argue that it is not crime. ${ }^{30}$ They contend that reliance only on deterrence and the prevention of harm as a justification for criminalisation may risk creating a 'morally-neutral criminal offence'. 31

Conscious of these legitimate criticisms and shortcomings, a number of scholars have sought to formulate normative justifications for cartel criminalisation that do not rely on a deterrence theory. These focus on delinquency and the cheating or subversion of the competitive process. In particular, Wardhaugh ${ }^{32}$ characterises cartels as attacking a valuable institution in liberal society (the market), while Whelan ${ }^{33}$ employs retribution theory to argue that cartel conduct can be conceptualised as theft or deception. However, arguments that cartels are inherently immoral, generally rely on the assumption (up to now untested empirically) that members of society expect markets to be competitive and understand that cartel conduct is harmful.

This paper fills this important gap in this literature by making the first empirical contribution to the cartel criminalisation debate. It analyses the results of public surveys carried out in the UK, Germany, Italy and the US, to determine: (i) whether ordinary members of the public expect prices charged by competing firms to be calculated independently of each other (a competitive norm); and (ii) the extent to which cartel conduct is viewed as objectionable by ordinary members of the public (a moral stigma). The results help us determine whether the central assumption made in the normative justifications for cartel criminalisation holds true, and the broader extent to which ordinary members of the public view cartel conduct as morally offensive enough to support criminalisation. In pursuit of these goals, section 1 sets

28. There are a number of studies that concur estimates in this region: PG Bryant and EW Eckard 'Price fixing: the probability of getting caught' (1991) 73(3) Rev Econ \& Stat 429445; E Combe and C Monnier 'Fines against hard core cartels in Europe: the myth of over enforcement' (2011) 56 Antitrust Bull 235; PL Ormosi 'A tip of the iceberg? The probability of catching cartels' (2014) 29(4) J Appl Econometrics 549-566. This is not an exhaustive list.

29. AJ Ashworth 'Is the criminal law a lost cause? (2000) $116 \mathrm{~L} \mathrm{Q} \mathrm{Rev} \mathrm{225;} \mathrm{AJ} \mathrm{Ashworth} \mathrm{and} \mathrm{L}$ Zedner 'Defending the criminal law: reflections on the changing character of crime, procedure and sanctions' (2008) 2 Crim L \& Phil 21; D Husak Overcriminalization and the Limits of Criminal Law (New York: Oxford University Press, 2009).

30. A Jones and R Williams 'The UK response to the global effort against cartels: is criminalization really the solution?' (2014) 2(1) J Antitrust Enforcement 100-125 at 102.

31. See discussion in $\mathrm{P}$ Whelan "Cartel criminalization and the challenge of "moral wrongfulness"' (2013) 33(3) Oxford J Legal Stud 535-561 at 541; and P Whelan 'Morality and its restraining influence on European antitrust criminalisation' [2009] TCLR 40.

32. B Wardhaugh 'a normative approach to the criminalisation of cartel activity' (2012) 32 Legal Stud 369.

33. P Whelan The Criminalization of European Cartel Enforcement: Theoretical, Legal and Practical Challenges (Oxford: Oxford University Press, 2014). 
out the main objections to extending the criminal law to cartel conduct, then section 2 identifies the main normative justifications that do not rely on deterrence arguments. The results of the survey are presented and interpreted in section 3, and the paper ends with concluding remarks.

The paper finds strong evidence to suggest that there is an assumption of competition between firms, and that most ordinary people understand that cartel conduct is harmful and should be punished. However, there is only weak support for imprisonment and perceptions of cartel wrongfulness are comparatively weak next to other forms of wrongdoing. These findings strengthen the case for cartel criminalisation, but also highlight the need for greater public awareness of competition law.

\section{OBJECTIONS TO CARTEL BEHAVIOUR BEING TREATED AS CRIME}

The question examined in this paper is not unique to competition law. There is a broader, long-standing debate among criminal lawyers over what categories of wrongdoing should rightly be treated as crime and the criteria against which they should be judged. The criticism of 'over-criminalisation' is largely directed at regulatory offences - those perceived as seeking to control conduct that lacks the moral condemnation purportedly inherent in crime. Green summarises the arguments of those concerned about over-criminalisation, as follows:

... applying criminal sanctions to morally neutral conduct is both unjust and counterproductive. It unfairly brands defendants as criminals, weakens the moral authority of the sanction, and ultimately renders the penalty ineffective. It also squanders scarce enforcement resources and invites selective and potentially discriminatory prosecution. We should reserve the criminal law - 'heavy artillery' of our legal system ... - for conduct that reflects the traditional conception of criminality. $^{34}$

These arguments have gained momentum in the UK in recent years, with the massive increase in the number of criminal offences adopted since the 1990s, which are aimed at regulating the behaviour of individuals and the firm. ${ }^{35}$ This regulation by criminal law, as some see it, is said to contribute to 'a significant blurring of the line between civil and criminal law' and has 'resulted both in the overuse of criminal law, outside of its traditional context, and its under enforcement'. ${ }^{36}$ One problem is that criminalisation is used as a 'quick political fix' where governments want to be seen to be taking an issue

34. S Green 'Why it's a crime to tear a tag off a mattress: overcriminalization and the moral content of regulatory offences' (1997) 46 Emory L J 1535 at 1536, citing FA Allen 'The morality of means: three problems in criminal sanctions' (1981) 42 U Pitt L Rev 737 at 738; and FB Sayre 'Public welfare offenses' (1933) 3(55) Colum L Rev 79-80. See also the difficulties associated with analysing criminalisation, discussed in $\mathrm{N}$ Lacey 'Historicising criminalisation: conceptual and empirical issues' (2009) 72(6) Mod L Rev 936-960.

35. 'Blair's "frenzied law making": a new offence for every day spent in office' The Independent 15 August 2006; for an empirical study of criminalization during this period, see J Chalmers and F Leverick 'Tracking the creation of criminal offences' (2013) Crim L Rev $543-560$.

36. Jones and Williams, above n 30, p 108. 
seriously, even though the non-criminal enforcement powers necessary to deal with the issue already exist. ${ }^{37}$

Jones and Williams aim a version of these arguments squarely at cartel criminalisation. They argue that the use of criminal law 'as a form of preferenceshaping disincentive to deter violations of anti-cartel rules ... does not consider whether there are any inherent differences between criminal and civil law which might prevent them appearing simply as different points on a continuous spectrum'. ${ }^{38}$ Drawing on the wider literature described above, they suggest there is something 'special' about the criminal law in that 'it signals moral condemnation of the criminalized conduct' and that 'It is not clear how the [cartel offence] reflects or builds moral stigma of prohibited conduct'. 39

However, the debate on criminalisation (in the common law world at least) is skewed by the difficulties inherent in providing clear distinctions between criminal and civil wrongdoing. Sets of descriptive criteria can be misleading. For example, although a mens rea requirement (a guilty mind) is generally necessary in criminal law and can be viewed as an expression of moral culpability, there are increasing instances of strict liability offences, which require only a guilty act. ${ }^{40}$ As mentioned in the introduction, in competition law it is difficult to discern a difference in the function of civil and criminal sanctions in relation to cartels, and it is notable that the standard of proof in civil 'hardcore' cartel cases is closer to the criminal standard than to the traditional civil balance of probabilities. $^{41}$

Those critical of widening criminalisation accept that civil and criminal law can be viewed as part of the same spectrum of policy tools available to regulate behaviour. ${ }^{42}$ However, they point to the question raised by Robinson: if criminal and civil law should be viewed in this way, why do legal systems still treat them as two distinct branches of enforcement? ${ }^{43} \mathrm{He}$ suggests that this is because criminal liability 'signals moral condemnation of the offender' by creating a specific criminal label that has a special condemnatory meaning. In doing so, the system communicates a clear condemnatory message. This is why, Jones and Williams reason,

37. See eg R White 'Civil penalties: oxymoron, chimera and stealth sanction' (2010) $126 \mathrm{~L}$ Q Rev 593.

38. A Jones and R Williams 'The UK response to the global effort against cartels: is criminalization really the solution?' (2014) 2(1) J Antitrust Enforcement 100-125 at 102.

39. Ibid; for examples, see A Ashworth 'Conceptions of overcriminalization' (2008) 5 Ohio St J Crim L 407-425 at 407-409; H Packer The Limits of the Criminal Sanction (Oxford: Oxford University Press, 1968) p 359; F Sayre 'Public welfare offences' (1933) 33 Colum L Rev 55.

40. See J Coffee 'Does "unlawful" mean "criminal"? Reflections on the disappearing tort/crime distinction in American law' (1991) 71 Boston U L Rev 193; discussed in Jones and Williams, above n 30, p 109; see also Ashworth and Zedner, above n 29.

41. See Napp Pharmaceutical Holdings Ltd and Subsidiaries $v$ Director General of Fair Trading, [2002] CAT 1 and JJB Sports PLC v Office of Fair Trading, [2004] CAT 17. In these cases, the Competition Appeals Tribunal stated that the level of strong and compelling evidence must take into account the seriousness of the alleged conduct, ensuring that the undertaking's presumption of innocence is respected, as well as any reasonable doubt that may exist.

42. D Friedman 'Beyond the tort/crime distinction' (1996) 76 Buffalo U L Rev 103 at 110; S Shavell 'Criminal law and the optimal use of nonmonetary sanctions as a deterrent' (1985) 85 Colum L Rev 1232 at 1235; and R Posner 'An economic theory of the criminal law' (1985) Colum L Rev 1193.

43. P Robinson 'The criminal-civil distinction and the utility of desert' (1996) 76 Boston U L Rev 201 at 203. 
... criminal law should not be utilized simply as a mechanism for creating deterrence without addressing the issue of moral stigma. If criminal law is to have an educative role, it must make clear what is morally reprehensible about the activity in question. ${ }^{44}$

Jones and Williams point to the fact the UK's cartel offence, under s 188 of the Enterprise Act 2002, was meant to 'send out a strong message to the perpetrators, their colleagues in business, the general public and the courts'. ${ }^{5}$ As part of the drive to bolster deterrence through criminalisation, the UK offence was in part aimed at hardening perceptions of cartels. The act of criminalising and the adoption of the standard of dishonesty (borrowed from the law of theft and fraud) would, it was thought, signal the seriousness of cartel practices. ${ }^{46}$ Yet, only five individuals have been convicted since the cartel offence was adopted 13 years ago. Moreover, the requirement of dishonesty - the moral element of the offence - was dropped by s 47 of the Enterprise and Regulatory Reform Act 2013. The government felt that the dishonesty element was hindering its enforceability because many jurors might not view cartel conduct as dishonest. $^{47}$

The central shortcoming of the dishonesty requirement was that it was intended to harden attitudes towards cartels, but depended on the jury being satisfied that the conduct was, by contemporary standards, objectively dishonest and that the defendant must have known their conduct was dishonest by those standards. ${ }^{48}$ It was thought that dishonesty would be obvious from the actions of those responsible, but the OFT found it difficult to present evidence in a manner that demonstrated this. In $R v$ Dean and Stringer, two defendants who did not dispute the facts of the case but simply argued that their conduct was not dishonest were acquitted by a jury in less than 2 hours. ${ }^{49}$ This was despite the fact that evidence was presented to suggest that the conduct was actively hidden from customers and that it resulted in margins increasing significantly. ${ }^{50}$ The case may have been an example of jury nullification, in that they simply did not accept that the conduct was crime - something that would support Jones and Williams' arguments. However, there were significant shortcomings to the prosecution's case (in particular, it is unclear whether the jury fully understood the alleged conduct) and juries in both Ireland and the US have been willing to convict cartel conduct in the past. ${ }^{51}$

44. Jones and Williams, above $\mathrm{n} 30, \mathrm{p} 113$.

45. Patricia Hewitt, Secretary of State for Trade and Industry. Hansard HC Deb, vol 383, col 48, 10 April 2002.

46. Hammond and Penrose, above n 16, at 7.3; See also M Furse and S Nash The Cartel Offence (Oxford: Hart Publishing, 2004) at 3.6-3.7; and Stephan, above n 15.

47. Department for Business, Innovation and Skills (BIS) A Competition Regime for Growth: A Consultation on Options for Reform (London: BIS, March 2011); BIS Growth, Competition and the Competition Regime: Government Response to Consultation (London: BIS, March 2012) p 1011.

48. $\quad R v$ Ghosh [1982] EWCA Crim 2. See Stephan, above n 15; P Whelan 'Improving criminal cartel enforcement in the UK: the case for the adoption of BIS's "Option 4" (2012) 8(3) Eur Competition J 589; A MacCulloch "The cartel offence: defining an appropriate "moral space", (2012) 8(1) Eur Competition J 73-93.

49. $R v$ Dean and Stringer (2015) Southwark Crown Court, unreported. See also Competition and Markets Authority, CMA statement following completion of criminal cartel prosecution (24 June 2015).

50. The case is unreported, but this author acted as an expert advisor to the defence team of Clive Dean and sat through the entire trial.

51. There are numerous examples in the US. In Ireland, the first instance of a jury conviction for cartel conduct was in DPP v Hegarty [2013] IECCA 66. 
Controversially, dishonesty was not replaced with another mens rea standard beyond intention. Those critical of the reform argued that it widened the scope of the offence beyond conduct that was clearly dishonest and therefore risked capturing legitimate business practices. ${ }^{52}$ To deal with these concerns, a series of carve-outs and defences where introduced, which allow defendants to escape criminal liability where they can demonstrate they did not enter (or did not intend to enter) into the arrangements openly. ${ }^{53}$ It can be argued that deliberately clandestine acts show that defendants knew they were engaging in wrongdoing and therefore acting immorally, yet this does not address the question of whether the conduct itself was immoral. ${ }^{54}$ The new offence significantly lowers the bar for proving liability, and the apparent circumventing of the offence's moral marker can be seen as vindicating Jones and Williams' contention that the offence is ineffective and that 'its existence might damage the condemnatory force of the criminal law more generally'. 55

Cartel criminalisation in the UK did not result from bottom-up moral outrage at the harmful effects and delinquent nature of cartel conduct. Instead, it was a top-down policy, reflecting the general willingness by the UK government to use a wide range of policy tools in regulatory control, including criminal ones. ${ }^{56}$ The same could be said about cartel criminalisation in other jurisdictions, as discussed above. Goodwin points out that for the law to serve a social function and guide their behaviour, people must have 'some good way of finding out what the law actually requires of them' and that there is something fundamentally flawed in the criminal law informing the public of what constitutes a crime rather than the other way around. ${ }^{57}$ Williams suggests that a forward-looking offence is flawed because 'the law cannot pull itself up by its own bootstraps in this way, any attempt to do so risks damaging both the process of cartel criminalisation and the criminal law more generally, ${ }^{58}$

A central tenet of the over-criminalisation argument is that harm alone does not provide an automatic justification for the use of criminal law. It is harm that underpins the deterrence arguments that motivate cartel criminalisation, as described in the introduction. Even some academics who broadly support criminalisation accept that deterrence theory is too simplistic and ignores 'the complex normative and social contexts in which cartel behaviour and enforcement occur'. 59 The over-criminalisation scholars contend that the key to the use of criminal law is its ability to signal society's moral condemnation of the harmful behaviour. This depends on both harm and moral culpability: in other words, both a guilty act and a guilty mind. Some go as far as to

52. See eg Enterprise and Regulatory Reform Public Bill Committee June 19, 2012, col 7 and 10 July 2012, col 540.

53. A Stephan 'The UK cartel offence: a purposive interpretation?' (2013) Crim L Rev 879892; P Whelan 'Section 47 of the Enterprise and Regulatory Reform Act 2013: a flawed reform of the UK cartel offence' (2015) 78(3) Mod L Rev 493-521.

54. Whelan, above $\mathrm{n} 48$.

55. Jones and Williams, above $\mathrm{n} 30, \mathrm{p} 108$.

56. See Law Commission Consultation Report 195 'Criminal liability in regulatory contexts: a consultation paper' (2010).

57. RE Goodin 'An epistemic case for legal moralism' (2010) 30(4) Oxford J Legal Stud 615633.

58. R Williams 'Cartels in the criminal landscape' in Beaton-Wells and Ezrachi, above n 11, pp 295-298.

59. C Parker 'Criminalisation and compliance: the gap between rhetoric and reality' in BeatonWells and Ezrachi, above n 11. 
suggest that moral culpability is more significant than harm. ${ }^{60}$ Jones and Williams say that 'in order to generate moral stigma, therefore, it would seem to be crucial for it to be identified with sufficient clarify what is morally reprehensible about cartel conduct; and what features of such activity distinguish it from other anti-competitive conduct that is not criminalised'. ${ }^{61}$ They suggest that when cartels were criminalised in the UK, they were not perceived as being morally wrong. ${ }^{62}$

This contention appears to be supported by the historically tolerant treatment of cartel arrangements in common law. ${ }^{63}$ These were expressed as recently as 2007 , in the case of Norris $v$ USA, when the House of Lords ruled on whether a British national could be extradited to the US to face price-fixing charges on the basis that cartel conduct amounted to the common law crime of conspiracy to defraud. In allowing Norris' appeal to dismiss the extradition, the House of Lords found, '... unless there were aggravating features such as fraud, misrepresentation, violence, intimidation or inducement of a breach of contract, cartel agreements were not actionable or indictable'. ${ }^{64}$ They overturned the Divisional Court's decision, which accepted an argument made in an academic article by Lever and Pike, that 'In many situations today third parties who deal with undertakings that are in fact parties to cartel agreements will proceed on the assumption that they are dealing with undertakings that are lawfully engaged in normal competition with each other'.65

One might also point to inconsistencies in how cartels are treated in law. For example, many competition law regimes do not apply to certain industries, such as agriculture and public utilities. ${ }^{66}$ They are also deliberately designed to apply to domestic markets only, meaning that it is lawful for firms to enter into export cartels. Thus behaviour, treated as crime domestically, is perfectly permissible (and sometimes even encouraged) when it is directed at foreign markets. ${ }^{67}$ However, exclusions of this nature are not unusual even in the most unequivocally severe forms of wrongdoing. In homicide, for example, we recognise the concept of a 'lawful killing'.

So the key criticisms of cartel criminalisation can be summarised as follows: (i) that it seeks to signal the seriousness of cartel conduct and does not make clear what is morally reprehensible about it; and (ii) that there is no clear evidence of society's moral condemnation of cartel conduct, or even an awareness that such conduct is harmful. For these reasons, cartel offences may be viewed as lacking legitimacy and as damaging

60. See eg A Ashworth 'Criminal attempts and the role of resulting harm under the code, and in the common law' (1987-1988) 19 Rutgers L J 725 at 742.

61. Jones and Williams, above $\mathrm{n} 30, \mathrm{p} 116$.

62. Ibid, p 113.

63. See eg Attorney General of the Commonwealth of Australia v Adelaide Steamship Co Ltd [1913] AC 781; Mogul Steamship Co Ltd v McGregor, Gow \& Co (1888) 21 QBD 544; (1889) 23; QBD 598 (CA); [1892] AC 25; Jones v North (1875) LR 19 Eq, 426, 429.

64. Norris $v$ Government of the United States of America and others [2008] UKHL 16 at 60.

65. J Lever and J Pike 'Cartel agreements, criminal conspiracy and the statutory 'cartel offence': parts I and II' (2005) 26(2) Eur Competition L Rev 90 at 95; Norris v Government of the United States of America and others [2007] EWHC 71 at 54 and 64; also discussed by Whelan, above n 33, p 103.

66. See GC Allen Monopoly and Restrictive Practices (London: George Allen \& Unwin, 1968) p 135, discussed in Harding and Joshua, above n 6, p 51.

67. M Martyniszyn 'Export cartels: is it legal to target your neighbour? Analysis in light of recent case law' (2012) 15(1) J Int'l Econ L181-222. 
all criminal law. We now turn to the normative arguments in favour of cartel criminalisation.

\section{NORMATIVE JUSTIFICATIONS FOR CARTEL CRIMINALISATION}

The arguments discussed in the previous section are to some extent flawed, because the greatest economic harm in the modern world comes not from traditional property offences such as theft or fraud, but from sophisticated forms of corporate wrongdoing that are largely hidden. Even when uncovered, many of these (including cartel conduct) can be complex and do not usually produce the necessary critical mass of harm needed to attract widespread media coverage or cause public outrage - yet they must be dealt with effectively all the same. The arguments have also failed to convince policy makers, who appear content with deterrence and the prevention of social harm, as sufficient justifications for cartel criminalisation. Nonetheless, finding a convincing response to these arguments may be important to the long-term success of cartel criminalisation. ${ }^{68}$ Indeed, the deterrence arguments largely relied upon by its proponents have some serious shortcomings. They generally rely on the economic paradigm of deterrence, which assumes that wrongdoers make rational choices about whether to engage in wrongdoing, weighing up the expected costs and benefits of doing so. ${ }^{69}$ As explained in the introduction, it is thought that only the threat of a custodial sentence can achieve a meaningful level of deterrence, because fines are unlikely to outweigh the potential cartel profits earned. However, the extent to which cartelists can be said to behave rationally is questionable. ${ }^{70}$

Whelan identifies three criticisms of modern deterrence theories. These are that: (i) it is difficult to quantify, with any accuracy, what a deterrent penalty should look like (especially as cartel prohibitions do not generally engage in any analysis of effects); (ii) strict adherence to deterrence theory would lead to unfair and disproportionate outcomes (eg imposing enormous punishment on a small violation because of perceived weaknesses in the rate of detection); and (iii) even if penalties were in some way 'optimal', the assumptions of rational decision making and the availability of accurate information about punishment and likelihood of detection are very doubtful. In particular, an empirical study conducted by the University of Melbourne, involving

68. See A Stephan 'Why morality should be excluded from the cartel criminalisation debate' (2012) 3(1) New J Eur Crim L 126-237; C Harding 'Business collusion as a criminological phenomenon: exploring the global criminalisation of business cartels' (2006) 14 Crit Crim 181; A MacCulloch 'The cartel offence and the criminalisation of UK competition law' [2003] J Bus L 615. It is also notable that Mill argued that the criminal law should only concern itself with behaviour that harms others: JS Mill On Liberty (Oxford: Oxford World's Classics, 1998 - first published 1859).

69. For an excellent discussion of these, see Whelan, above $\mathrm{n} 33, \mathrm{p} 27$, citing the examples of $\mathrm{W}$ Wils 'Is criminalization of EU competition law the answer?' in K Cseres, MP Schinkel and F Vogelaar (eds) Criminalization of Competition Law Enforcement: Economic and Legal Implications for the EU Member States (Cheltenham: Edward Elgar, 2006); T Clavani 'Cartel penalties and damages in Ireland: criminalization and the case for custodial sentences' in Cseres et al, ibid; Stephan, above n 15; D Ginsburg and J Wright 'Antitrust sanctions' (2010) 6(2) Competition Pol'y Int'l 187.

70. See A Stephan and A Nikpay 'Leniency decision-making from a corporate perspective: complex realities' in C Beaton-Wells and C Tran (eds) Anti-Cartel Enforcement in a Contemporary Age: The Leniency Religion (Oxford: Hart Publishing, 2015). 
a cross-section of the business community in Australia, found that the process that is likely to surround any decision to form a cartel is far more complicated than is generally assumed in deterrence theory. ${ }^{71}$ The study also suggested that the deterrent effect of incarceration may be exaggerated. ${ }^{72}$

Arguments based solely on social harm are also problematic, because cartel laws make little or no attempt to quantify the harm caused. In fact, they punish infringements regardless of their effect or even the extent to which they were actually implemented. Unlike theft or fraud, the harm caused is not always obvious either. It amounts to an increase in price to a level higher than would otherwise be the case, but it can be tricky to distinguish the overcharge from legitimate reasons why the price might have gone up during the relevant period (eg increased costs). ${ }^{73}$ Moreover, most cartels appear to be motivated - in part at least - by a crisis in the industry or fear of bankruptcy. ${ }^{74}$ Not only does this make it less likely that cartelists behave rationally; it also risks skewing the moral responsibility for their actions, as price fixing out of greed becomes price fixing out of fear of losing one's livelihood. However, this does not change the means by which a cartel outcome is achieved (Robin Hood stole regardless of his good intentions), nor the harmful effects to consumers. ${ }^{75}$

Conscious of these shortcomings and unsatisfied with the harm and deterrence-based arguments for cartel criminalisation, a number of academics have sought to formulate normative justifications. The first of these argues that the moral offensiveness of cartel conduct is heightened by their characteristic determination to defy the prohibition and take steps to avoid detection. Harding and Joshua argue that the act of hiding their actions from customers, the authorities and others within the firm creates a 'spiral of delinquency', since it is not simply the anti-competitive behaviour in itself, but also the determination to defy the prohibition that contributes to a heightened perception of delinquent behaviour. ${ }^{76}$ The further cartelists go to hide their behaviour, the greater the spiral of delinquency. Cartels typically go as far as to meet in secret locations, use codenames and communicate through unregistered mobile phones and private email accounts. ${ }^{77}$ The moral wrongfulness therefore arises not only from the act of price fixing itself, but from the fact it is hidden. Indeed, it is hard to think of a legitimate reason why a cartelist might take such drastic steps to conceal their behaviour other than a good understanding that it is illegal. This argument is particularly relevant to the UK's revised cartel offence, discussed in the previous section, but it relates more to deliberate rule breaking than the immoral nature of the act itself.

71. C Beaton-Wells and C Parker 'Justifying criminal sanctions for cartel conduct: a hard case' (2013) 1(1) J Antitrust Enforcement 198.

72. Ibid.

73. See Oxera Quantifying Antitrust Damages: Towards Non-binding Guidance for Courts, study prepared for the European Commission (December 2009), available at http://ec.europa. eu/competition/antitrust/actionsdamages/quantification_study.pdf (accessed 20 December 2016).

74. A Stephan 'Price fixing during a recession: implications of an economic downturn for cartels and enforcement' (2012) 35(3) World Competition 511-528.

75. See discussion by Whelan, above $\mathrm{n} 33$, pp 92-95.

76. C Harding 'The anti-cartel enforcement industry: criminological perspectives on cartel criminalisation' (2006) 14 Crit Crim 181; Harding and Joshua, above n 6, p 51.

77. A Stephan 'See no evil: cartels and the limits of antitrust compliance programs' (2010) 31(8) The Company Lawyer 231-239. 
The second of these focuses on the act of price fixing as a form of cheating. MacCulloch points out that the "criminal trial is inherently a "moral space" where ... the guilty are punished because of their wrongdoing - it is the actions of the accused, their wrongdoing, which is judged' ${ }^{78}$ He suggests that the two most convincing conceptions for highlighting the wrong in cartel behaviour are "cheating, 79 and what Beaton-Wells and Fisse describe as the 'subversion of competition', ${ }^{80}$ which we might think of as being equivalent to insider trading. MacCulloch contends that.

Both represent the concern that cartel behaviour is wrong in that the act of making or implementing a cartel arrangement denies the marketplace of the legitimate expectation of a competitive process. The cartelist 'subverts' that process or 'cheats' the marketplace by stepping outside of the legitimate process that other market players, and the wider economy, legitimately expect. The wrong in the conduct is that the cartel members have chosen to break the rules of the game.' ${ }^{, 81}$

This is consistent with the work of Stuart Green, who also rejects the idea that pure deterrence or harm-prevention arguments can justify criminalisation. ${ }^{82}$ Instead, he argues that 'moral wrongfulness' of practices like insider trading can be found in existing moral norms, such as deception and cheating. ${ }^{83}$ Like Harding and Joshua, Green also suggests that the source of moral content is not only the underlying act, but the intentional violation, concealment and defiance of the law. ${ }^{84}$

Wardhaugh takes the cheating argument a step further, arguing that cartel harm strikes at a valuable institution that provides an individual with the ability to secure his own welfare in a liberal society. ${ }^{85}$ He does this by drawing on the works of JS Mill ${ }^{86}$ and J Rawls. ${ }^{87}$ Wardhaugh argues that because cartels undermine 'an important social institution, namely the market', cartel activity can legitimately be criminalised. He views the market as an instrument of distributive justice. This allows for a normative justification of cartel criminalisation that does not make the additional inference that harms to all social institutions should be subject to criminal sanctions. ${ }^{88}$ The argument is therefore that criminalisation can be justified on the grounds that cartelists fail to "play by the rules' of the marketplace and that they 'carve out a self-exception to the general social rules governing distributive justice'. ${ }^{89}$ This is a very convincing argument, if indeed it is the case that members of the public value the rules of the market in this way.

78. MacCulloch, above n 48.

79. SP Green Lying, Cheating and Stealing: A Moral Theory of White Collar Crime (Oxford: Oxford University Press, 2006); and C Beaton-Wells 'Capturing the criminality of hard core cartels: the Australian proposal' (2007) 31 Melbourne U L Rev 675.

80. C Beaton-Wells and B Fisse Australian Cartel Regulation: Law, Policy and Practice in an International Context (Cambridge, UK: Cambridge University Press, 2011).

81. MacCulloch, above n 48, p 85; see also Lever and Pike, above n 65.

82. Green, above $n 79$.

83. See Green, above n 34, at 1551, discussed in Whelan, above n 31, pp 5-6.

84. Ibid, pp 1603-1535.

85. B Wardhaugh Cartels, Markets and Crime: A Normative Justification for the Criminalisation of Economic Collusion (Cambridge, UK: Cambridge University Press, 2014), Chapter 1; B Wardhaugh 'A normative approach to the criminalisation of cartel activity' (2012) 32 Legal Stud 369.

86. JS Mill On Liberty (London: Parker, 1859).

87. J Rawls A Theory of Justice (Cambridge, MA, Harvard University Press, 1999).

88. Wardhaugh, n 88, pp 49-51.

89. Ibid, p 49 . 
The third argument is made by Whelan and focuses on whether there is a strong basis for cartel criminalisation in retribution theory. ${ }^{90}$ This suggests that punishment should arise where individuals have made choices that society deems wrong, rather than focusing on the prevention of future crime. ${ }^{91}$ Whelan discusses possible sources for the moral wrongfulness of cartel conduct, looking first at stealing. He points out that, while cartels clearly result in higher prices, the ownership of the overcharge could be questioned. Like Wardhaugh, he suggests that this could be overcome not through a legal definition of ownership, but by the presumption that arises out of the 'endorsement of free market economics by European citizens', which gives rise to consumers' 'right to a competitive market' ${ }^{92}$ He also points out that such a presumption is consistent with competition law's emphasis on consumer welfare. ${ }^{93}$ It may also be found in consumers' right to obtain compensation where they have been victims of cartel overcharging. ${ }^{94}$ However, it is not easy to reconcile these considerations with the firm's ownership over its profits. Indeed, a firm engaged in price fixing can be said to be maximising its profits, rather than intending to permanently deprive consumers of their money.

Turning next to deception, Whelan finds that situations where a cartelist expressly tells their customer they are price fixing, and where they falsely tell their customer they are not, are straightforward. ${ }^{95}$ The first is not deceptive, while the second clearly is. The latter is easily observed in the case of bid-rigging, because participants are being asked to take part in the explicitly competitive process of submitting an independent bid. So the submission of a false bid or an arrangement through which the winning bid has been

90. Whelan, above $\mathrm{n} 33$, ch 4 and Whelan, above $\mathrm{n} 31$; he employs a tripartite framework set out by the American legal theorist Green and involves culpability (the state of mind of the defendant), social harmfulness (the consequences of the conduct) and moral wrongfulness (the conduct in question violates a moral norm). Green does not suggest that these act as a set of necessary conditions for criminalisation, but only as a framework to help us understand the complexity of white collar crime: S Green 'Moral ambiguity in white collar criminal law' (2004) 18 Notre Dame J L Ethics \& Pub Pol'y 501.

91. See H Packer The Limits of the Criminal Sanction (Oxford: Oxford University Press, 1968).

92. Whelan, above $\mathrm{n} 31, \mathrm{p} 10$.

93. Consumer and producer welfare concern the distribution of wealth or profit in an economy between those selling a product and those buying it. Many economists contend that it is the total welfare in the market that is important, and that the way in which competition policy is aimed at maximising consumer welfare can actually reduce welfare in some markets. They argue that the fact that a total welfare standard results in more wealth transfers from consumers is mitigated by the fact that any extra profits enjoyed by the firm will benefit shareholders and employees (who are also consumers) and allow the firm to better innovate and expand. This is a separate question to cartel harm, which is generally detrimental to welfare in the market regardless of whether there is an emphasis on consumer or total welfare. Contrast DW Carlton 'Does antitrust need to be modernized?' (2007) 21(3) J Econ Perspectives 155-176 with R Pittman 'Consumer surplus as the appropriate standard for antitrust enforcement' (2007) 3 Competition Pol'y Int'l 205. In addition, under Art 101(3), in order to gain an exception from a breach of Art 101(1), a firm must demonstrate that any countervailing efficiencies that arise out of the arrangement benefit consumers.

94. Directive 2014/104/EY of the European Parliament and of the Council of 26 November 2014 on certain rules governing actions for damages under national law for infringements of the competition law provisions of the Member States and of the European Union [2014]; Case C-453/99, Courage Ltd v Bernard Crehan [2001] ECR I-6297 and joined cases C-295/04 to C-298/04, Vincenzo Manfredi and others v Lloyd Adriatico Assicurazioni Spa and others [2006] ECR I-6619.

95. Whelan, above n 31, pp 16-21. 
decided in advance by the bidders is clearly deceptive and, one might suggest, morally repugnant. However, many cartels fall into a third, more problematic, scenario. This is where the cartelist is silent as to whether they are price fixing. Here, deception can only exist if there is a strong positive presumption that firms behave competitively in a free market. Cartels typically involve efforts to hide their activities. One might argue that this secrecy gives rise to a false belief among consumers,${ }^{96}$ but again that only holds true if consumers accept and expect a competitive norm. Whelan also considers whether cartels break a moral norm against cheating one's customers, but finds difficulty in identifying the 'unfair advantage' that the cartelist intends to obtain.

The key issue underpinning the strength of these normative arguments in support of criminalisation is the extent to which ordinary people expect markets to be competitive and recognise the harmful nature of cartels. In particular, these statements must hold true if cartels do indeed 'break the rules of the game', strike at an 'important social institution' (the competitive market) or amount to a deception even where no false statements have been made. In relation to his retribution arguments, Whelan states that.

For a cartel activity to have a negative impact, one must demonstrate a positive feature of the counterfactual: one must demonstrate that a free market is valued by society .... The strength of a retribution-based criminalization argument therefore depends upon the acceptance by society of the value of the free market. ${ }^{97}$

He then goes on to survey various public attitudes studies examining whether members of the public prefer the free market. In particular, the 2003 Pew Global Attitudes Project that found that 33 of 44 countries surveyed felt that people are better off if they live in a free market economy. ${ }^{98}$ But he concludes that a lack of empirical evidence directly relating to cartels is a particular weakness in the existing literature. ${ }^{99}$ Harding and Joshua suggest it is not unreasonable to assume that competitive prices are the norm and are expected by consumers, but no previously published empirical studies directly deal with this question. ${ }^{100}$

\section{EMPIRICAL FINDINGS ON PUBLIC ATTITUDES AND CARTEL CRIMINALISATION}

This paper now turns to the empirical findings on the attitudes and perceptions of cartels among ordinary members of the public. These are important in helping us to investigate the criminalisation question in a number of respects. First, they allow us to test the hypothesis that consumers expect markets to be competitive and for separate undertakings to set their prices independently of each other. These questions are key to both dealing with the over-criminalisation criticisms and lending support to the normative justifications for a cartel offence - in particular, arguments that cartel conduct amounts to a moral wrong (regardless of harm or deterrence) even where there

96. This was argued in Lever and Pike, above $\mathrm{n} 65$, at 95 and accepted by the High Court in the extradition case: Norris $v$ Government of the USA [2007] EWHC 71 (Admin), [2007] 1 WLR 1730.

97. Whelan, above $\mathrm{n} 33, \mathrm{p} 92$.

98. Pew Global Attitudes Project Views of a Changing World, Second Major Report of the Pew Global Attitudes Project (June 2003).

99. Whelan, above n 33, p 103.

100. Harding and Joshua, above n 6, ch 2.3 . 
is no explicit deception. Secondly, they help us understand the extent to which there is popular condemnation of cartel conduct, the level of stigma attached to it and the severity of punishment that is thought appropriate.

The empirical study consisted of four public surveys carried out online between 27 June and 15 July 2014, in the UK, Germany, Italy and the US. ${ }^{101}$ These were designed, translated and piloted within the University of East Anglia's Centre for Competition Policy, with the assistance of a number of competition law academics from each of the subject jurisdictions. ${ }^{102}$ The fieldwork was done by YouGov PLC in the UK, Germany and the US, and in cooperation with Research Now in Italy. The sample was selected from online panels typically used for election polls and general market research. These samples were selected to be representative of the general population in each country according to a list of demographic characteristics. The sample sizes were 2,509 (UK), 2,648 (Germany), 2,521 (Italy) and 2,913 (USA). These surveys were actually a follow-up of a 2007 study carried out only in the UK, which asked a variety of questions relating to price fixing. ${ }^{103}$

The decision to undertake a comparative study was motivated by a desire to see whether different cultures and levels of enforcement have resulted in diverging public attitudes. The US was included because it has by far the most active criminal antitrust enforcement regime in the world. Germany and Italy were selected so that attitudes in the UK could be compared with those of other EU Member States. ${ }^{104}$ Any significant divergence in opinion within the EU would be significant, because the most harmful multinational cartels are dealt with by the European Commission under the EU's purely civil enforcement regime.

\subsection{Do consumers expect independent pricing?}

Respondents in the study were not given any information about how cartels are treated in law or of the dominant view among academics and policy makers, that such practices are overwhelmingly harmful and should be prohibited. Care was also taken in the question ordering, to limit the scope for information contained in earlier questions influencing responses later in the survey. The survey began with two general introductory questions about markets, including one about government intervention (Figure 1).

The responses were broadly what one would expect, reflecting a stronger faith in the free market among Americans, as compared to more sceptical Europeans. Within Europe, one can see the more neoliberal leanings of the British and Germans as compared to Italians. Before being asked whether cartel conduct was harmful or should be punished, respondents were asked about their expectations of how competing

101. The study was funded by the Centre for Competition Policy, with money awarded to it by the Economic and Social Research Council (UK).

102. For a full list of these and more detail on the methodology, see A Stephan 'Survey of public attitudes to price fixing in the UK, Germany, Italy and the USA' CCP Working Paper 15-8, available at http://papers.ssrn.com/sol3/papers.cfm?abstract_id=2642181 (accessed 23 September 2016). Questions generally gave respondents two alternative options and they were asked to indicate which they agreed with more.

103. This study was cited in the UK's decision to reform the cartel offence under the Enterprise and Regulatory Reform Act 2013. See BIS, A Competition Regime for Growth, above n 47. The results of the 2007 study can be found in A Stephan 'Survey of public attitudes to price fixing and cartel enforcement in Britain' (2008) 5(1) Competition L Rev 123-145.

104. At the time of writing, the UK had held a referendum in which a majority of the population chose to leave the EU, but the UK is still at this time a full EU Member State. 
Citizen A believes that a free market economy, in which government control is kept to a minimum, is the best available economic system for creating wealth and prosperity.

\section{Citizen $B$ believes that wealth and prosperity can be better achieved through greater government intervention in the economy.}

Which citizen do you agree with? Please tick $(\curvearrowleft$ ) only one.

\begin{tabular}{|c|c|c|c|c|}
\hline & GB & DE & IT & US \\
\cline { 2 - 5 } & & & & \\
\hline $\begin{array}{r}\text { Agree with A } \\
\text { (strongly agre) }\end{array}$ & $\begin{array}{c}48 \% \\
(18 \%)\end{array}$ & $\begin{array}{c}48 \% \\
(19 \%)\end{array}$ & $\begin{array}{c}44 \% \\
(17 \%)\end{array}$ & $\begin{array}{c}59 \% \\
(42 \%)\end{array}$ \\
\hline $\begin{array}{r}\text { Agree with B } \\
\text { (strongly agree) }\end{array}$ & $\begin{array}{c}31 \% \\
(9 \%)\end{array}$ & $\begin{array}{l}36 \% \\
(9 \%)\end{array}$ & $\begin{array}{c}47 \% \\
(13 \%)\end{array}$ & $\begin{array}{c}25 \% \\
(10 \%)\end{array}$ \\
\hline & & & & \\
\hline Neither / DK & $21 \%$ & $17 \%$ & $9 \%$ & $17 \%$ \\
\hline
\end{tabular}

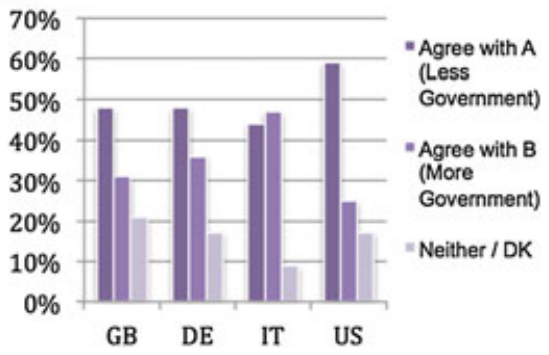

Figure 1: Government intervention in markets. [Colour figure can be viewed at wileyonlinelibrary.com]

When you buy a product or service, you normally have a choice between different businesses in competition with each other. Think about how you expect these businesses to have set their prices.

Citizen A expects each business they buy from to have set their prices independently of each other. They object to firms talking with each other about the prices they charge.

Citizen B does not expect each business they buy from to have set their prices independently of each other. They consider it normal for competing businesses to talk to each other about the prices they charge.

Which citizen do you agree with? Please tick ( $($ ) only one.

\begin{tabular}{|c|c|c|c|c|}
\hline & GB & DE & IT & US \\
\cline { 2 - 5 } & & & & \\
\hline $\begin{array}{r}\text { Agree with A } \\
\text { (strongly agree) }\end{array}$ & $\begin{array}{c}65 \% \\
(36 \%)\end{array}$ & $\begin{array}{c}64 \% \\
(43 \%)\end{array}$ & $\begin{array}{c}64 \% \\
(35 \%)\end{array}$ & $\begin{array}{c}54 \% \\
(30 \%)\end{array}$ \\
\hline $\begin{array}{r}\text { Agree with B } \\
\text { (strongly agree) }\end{array}$ & $\begin{array}{c}22 \% \\
(4 \%)\end{array}$ & $\begin{array}{c}27 \% \\
(8 \%)\end{array}$ & $\begin{array}{c}30 \% \\
(8 \%)\end{array}$ & $\begin{array}{c}27 \% \\
(7 \%)\end{array}$ \\
\hline Neither/DK & $13 \%$ & $8 \%$ & $6 \%$ & $19 \%$ \\
\hline
\end{tabular}

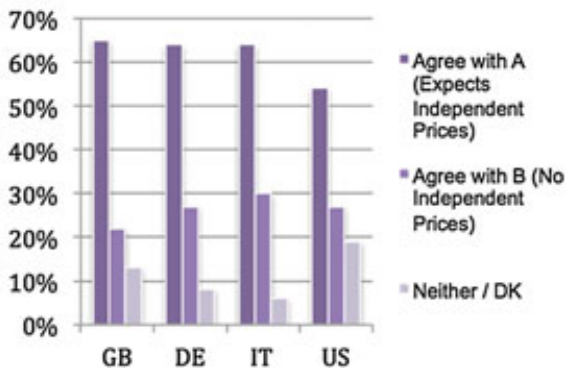

Figure 2: Expectations about how businesses set prices. [Colour figure can be viewed at wileyonlinelibrary.com]

businesses set their prices (Figure 2). This question is very significant for the purposes of this paper, and it is important to stress that respondents had no information about price fixing, its treatment in law or the harm it can cause.

For the purposes of the criminalisation debate discussed above, this question provides a very significant set of results. Around two thirds of respondents in the UK, Germany and Italy expect competitors to set their prices independently of each other. Less than one in three felt that it was normal for competing businesses to talk 
to each other about prices (one in five in the UK). These results suggest that consumers are far from indifferent to the way in which firms calculate their prices, with two key implications. The first is that there appears to be a competitive norm in each of these countries. Indeed, members of the public both expect businesses to set their prices independently of each other, and object to them talking to each other about the prices they charge. This appears to lend support to Wardhaugh's assertion about the market as an important social institution and the way in which citizens value it. If the norm is for markets to be competitive, then it is easier to characterise cartels as subverting the 'rules of the game'. Interestingly, the proportion of people expecting independent pricing was lower in the US, despite Americans' more favourable view of the free market. This could reflect how perceptions are primarily shaped by notions of fairness or an awareness of the harm that results from competitors colluding on price (discussed below). Whatever the main driver, ordinary members of the public appear to value and expect the process of competition.

The second implication is that where competing firms depart from the competitive process to form a cartel, most consumers will continue to rely on the assumption that prices are being calculated independently, unless told otherwise by the firms. This may very well constitute an empirical basis for arguing that attempts to hide or suppress the disclosure of information about the existence of a cartel amount to deception, in the way that Whelan describes. It also helps us to deal with the problematic scenario of a cartel that fails to inform customers of its existence but makes no false statements or attempts at positive deception. The clear expectation of independent pricing arguably makes such a cartel objectionable, in the same vein as deliberate misrepresentations or the submission of a rigged bid. It also suggests that the UK's decision to reform its cartel offence around 'openness' is far from flawed. ${ }^{105}$ If we know that consumers expect competitive pricing and object to collusion, then the clandestine act of price fixing is immoral, both as a deception and as an act of delinquency (to use Harding and Joshua's term), in deliberately engaging in unlawful behaviour that is hidden.

\subsection{How objectionable is price fixing?}

The study then turned to views on cartel conduct. The phrase 'price fixing' was not initially used. Instead, respondents were given an introductory question that set out a simple scenario involving two corner shops. They were asked whether they thought it was good or bad for those corner shops to meet up once a month and agree the prices they charge for groceries. Around two thirds of respondents (almost three quarters in the UK and Germany) felt it was bad. Those who expected prices to be calculated independently mapped very strongly on to this group, with a significant proportion of those not expecting independent pricing recognising the negative effects when presented with a specific scenario. Respondents were then asked a direct question about price fixing.

This question introduces the phrase 'price fixing' and asks whether it is harmful and should be punished (Figure 3). We see respondents from the previous questions answering consistently, with an increase in the majority who are hostile to cartel behaviour. In this question, some of the increase may be due to negative connotations surrounding the phrase 'price fixing' and the fact the question mentions punishment. It may also be due to their developing a better understanding of the conduct being examined in these surveys. Nonetheless, a clear majority of respondents in each of the four jurisdictions recognise that price fixing is harmful to customers and feel that

105. Whelan, above $\mathrm{n} 48$.

(C) 2017 The Authors Legal Studies published by John Wiley \& Sons Ltd on behalf of Society of Legal Scholars 
Price fixing is where competing businesses agree the prices they will each charge.

Citizen A believes that price fixing is a harmless business practice, that businesses should be free to set prices how they want and that price fixing should not be punished.

Citizen B believes that price fixing is harmful to customers, that each business should set its own price independently, and that such behaviour should be punished.

Which citizen do you agree with? Please tick $(レ)$ only one

\begin{tabular}{|c|c|c|c|c|}
\hline & GB & DE & IT & US \\
\hline & & & & \\
\hline \begin{tabular}{rl|l|} 
Agree with A \\
(strongly agree)
\end{tabular} & $\begin{array}{c}7 \% \\
(2 \%)\end{array}$ & $\begin{array}{c}12 \% \\
(5 \%)\end{array}$ & $\begin{array}{c}20 \% \\
(6 \%)\end{array}$ & $\begin{array}{c}15 \% \\
(6 \%)\end{array}$ \\
\hline $\begin{array}{r}\text { Agree with B } \\
\text { (strongly agree) }\end{array}$ & $\begin{array}{c}79 \% \\
(48 \%)\end{array}$ & $\begin{array}{c}78 \% \\
(55 \%)\end{array}$ & $\begin{array}{c}73 \% \\
(41 \%)\end{array}$ & $\begin{array}{c}66 \% \\
(42 \%)\end{array}$ \\
\hline & & & & \\
\hline Neither / DK & $14 \%$ & $11 \%$ & $8 \%$ & $20 \%$ \\
\hline
\end{tabular}

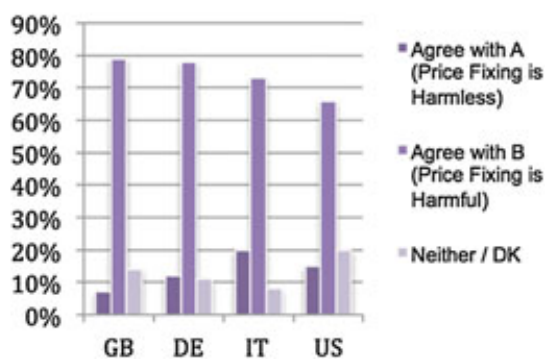

Figure 3: Price-fixing. [Colour figure can be viewed at wileyonlinelibrary.com]

it is deserving of punishment. It is important to bear in mind that respondents had no information about how price fixing was actually treated, in law, in their jurisdiction or anywhere else.

Later in the survey, each respondent was asked, 'As far as you are aware, is it illegal in your country for competing businesses to meet up and agree on what prices to charge their customers?' Only 53\% of Britons and Italians thought price fixing was illegal and, surprisingly, only $41 \%$ of Americans. The proportion in Germany was significantly higher $(75 \%)$, but this may have been due to a number of high-profile cases that occurred in Germany over the 6-week period immediately preceding the fieldwork. ${ }^{106}$ So in the UK, Italy and the USA, a significant proportion of respondents believe that price fixing is harmful and should attract punishment, despite not being aware that it is in fact illegal in their country. This is significant because it means the perceptions of many respondents were not shaped by their knowledge that cartel conduct was unlawful. They reasoned that cartels are harmful and should be punished despite the law. The fact that the lowest awareness of the law was among citizens of the most active cartel enforcement jurisdiction in the world suggests that enforcement has had very limited educative effect. Criminal law there is not pulling itself up by its own 'bootstraps' in just the way Jones and Williams warn. However, poor knowledge of the law does not necessarily mean weak support for criminal sanctions.

In order to determine how objectionable consumers felt price fixing was, the surveys turned to questions about sanctions and comparisons with other, better known, forms of wrongdoing. Those respondents who felt price fixing was harmful and should be punished were first asked what forms of punishment they agreed with in relation to the firm. They were given the option to choose as many as they wanted from a list of three (public naming and shaming, a fine at least equal to the illegal cartel profits and

106. 'Five German brewers fined $€ 106.5 \mathrm{~m}$ for price-fixing' Financial Times 13 January 2014; 'German sausage cartel caught bangers to rights' The Guardian 15 July 2014; 'German cartel inquiry launched into Deutsche Bahn' Financial Times 30 January 2014. 
Five large businesses agree to fix prices so that their customers are charged more than would be the case if they acted independently and so that each will earn extra profit. Which if any form of punishment do you think each of these businesses should face? Please select as many as you feel should apply.

\begin{tabular}{|l|c|c|c|c|}
\cline { 2 - 5 } & GB & DE & IT & US \\
\hline $\begin{array}{l}\text { Public Naming and } \\
\text { Shaming }\end{array}$ & $78 \%$ & $61 \%$ & $55 \%$ & $65 \%$ \\
\hline $\begin{array}{l}\text { A fine at least equal to } \\
\text { the illegal profits made }\end{array}$ & $77 \%$ & $78 \%$ & $66 \%$ & $68 \%$ \\
\hline $\begin{array}{l}\text { Compensation to the } \\
\text { customers who have } \\
\text { been over-charged }\end{array}$ & $72 \%$ & $48 \%$ & $52 \%$ & $68 \%$ \\
\hline $\begin{array}{l}\text { None of the above / DK } \\
\text { Non }\end{array}$ & $2 \%$ & $2 \%$ & $2 \%$ & - \\
\hline
\end{tabular}

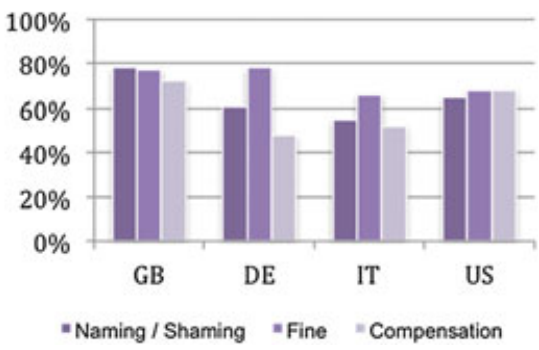

Figure 4: Appropriate sanctions for the firm. [Colour figure can be viewed at wileyonlinelibrary.com]

compensation to customers who had been overcharged) or were given the option to indicate that they felt none of these were appropriate.

Figure 4 shows how there was strong support for all three of these - especially in the UK. One might interpret these results as an indication that price fixing is viewed as being serious enough to warrant more than simply a remedy that restores the status quo, absent the cartel. In particular, strong support for public naming and shaming, in addition to a fine and compensation, suggests popular support for a punitive approach to tackling cartels, not a purely regulatory one. Only a very small number felt that none of the three options was appropriate. The same group of respondents were then asked what forms of punishment they felt were appropriate for the individuals responsible. The options were public naming and shaming, a personal fine, a ban from holding senior managerial positions and imprisonment.

While there is strong support for the first three sanctions (in particular, a personal fine and a disqualification order), the limits to people's willingness to condemn cartel behaviour become apparent in relation to imprisonment. If taken as a proportion of the entire sample (not just those who feel that price fixing should be punished), support for the imprisonment of cartelists stands at around one in five in the UK, Germany and Italy and around one in four in the US. This may reflect an absence of the clear sense of moral stigma associated with traditional crime. However, relatively weak support for imprisonment does not necessarily mean that cartel conduct should not be treated as a crime. Moreover, the figure of $27 \%$ support for imprisonment in the UK (in Figure 5) was only $11 \%$ in the 2007 study, when the question was put to a similar subset of respondents. This amounts to more than a doubling in support for imprisonment in the space of 7 years. It might be explained by greater general awareness of competition issues through the advocacy work of the OFT/CMA or it may simply reflect a greater hostility towards corporate wrongdoing following the financial crisis in late 2007-8.

The same group of respondents were then asked to think about how serious or objectionable price fixing was compared to other forms of wrongdoing. These ranged from traditional offences like theft and assault, to other forms of business wrongdoing, such as tax evasion and insider trading. The aggregate results across the four jurisdictions are set out in Figure 6. 
The decision to fix prices is usually made by a number of individuals within a business. Which if any forms of punishment do you think each of these individuals should face? Please tick ( $)$ as many that you feel should apply.

\begin{tabular}{|c|c|c|c|c|}
\hline & GB & $\mathrm{DE}$ & IT & US \\
\hline $\begin{array}{l}\text { Public Naming and } \\
\text { Shaming }\end{array}$ & $69 \%$ & $47 \%$ & $49 \%$ & $58 \%$ \\
\hline A personal fine & $61 \%$ & $62 \%$ & $59 \%$ & $67 \%$ \\
\hline $\begin{array}{l}\text { A ban from holding } \\
\text { senior managerial } \\
\text { positions in } \\
\text { businesses }\end{array}$ & $75 \%$ & $68 \%$ & $63 \%$ & $50 \%$ \\
\hline Imprisonment & $27 \%$ & $28 \%$ & $26 \%$ & $36 \%$ \\
\hline $\begin{array}{l}\text { None of the above / } \\
\text { DK }\end{array}$ & $6 \%$ & $3 \%$ & $4 \%$ & - \\
\hline
\end{tabular}

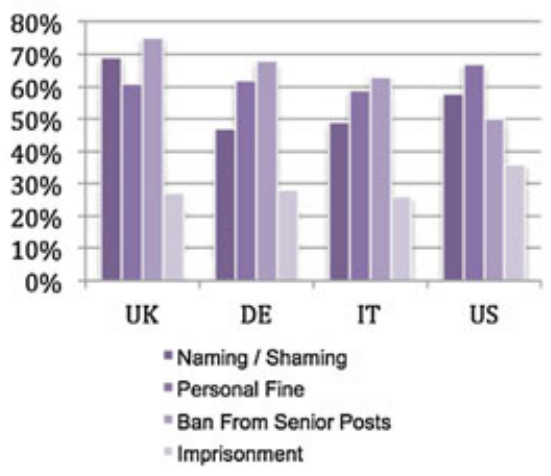

Figure 5: Appropriate sanctions for the individual. [Colour figure can be viewed at wileyonlinelibrary.com]

Unsurprisingly, respondents felt strongly that offences resulting in physical harm (assault, drink driving, misleading consumers about product safety) were significantly more serious than price fixing. The key comparisons were with theft, fraud and other forms of financial crime. Respondents were fairly split on whether theft was more serious or about the same as price fixing, and the results were similar in relation to corporate tax evasion. But when asked to compare with fraud, a clear majority of respondents in all jurisdictions except Italy felt that price fixing was about as serious (around $40 \%$ felt that it was less serious). The results were similar in relation to insider trading too. However, for all of these offences, the net results indicated that price fixing was viewed as less objectionable than any of these offences. Indeed, price fixing was only viewed as being significantly more serious than copyright theft.

On the one hand, we might interpret these results as reflecting a weak moral opprobrium in relation to price fixing among large sections of the population in each of the four jurisdictions. Yet they may simply reflect how the above-mentioned offences are better known and how the harm they cause is better understood. A key problem in competition law enforcement is effective dissemination of information and increasing public awareness of the harm caused by anti-competitive conduct. As this tends to be passed on and shared among a large number of final consumers, it is often hard to identify a critical mass of harm or a clear group of victims. ${ }^{107}$ This lack of awareness is reflected in the above results on whether respondents thought that price fixing was illegal, and in the fact that US attitudes appear to be no more hardened than those in Europe, despite it being by far the most active criminal cartel enforcement regime in the world. It is also notable that research undertaken by the CMA shows that as many as three quarters of businesses in the UK (albeit mainly small and medium-sized firms) have either never heard of competition law or describe their familiarity with it as

107. See generally A Stephan "Cartel criminalisation: the role of the media in the "battle for hearts and minds" 'in Beaton-Wells and Ezrachi, above n 11. 
A person physically attacking another person.

Driving while under the influence of drink or drugs.

A company misleading consumers about the safety of goods.

A company manipulating its accounts to avoid paying tax.

A person stealing another's property

A person tricking someone into giving their money (fraud).

\section{A person using insider information in deciding to buy or sell shares.}

A person illegally downloading music.
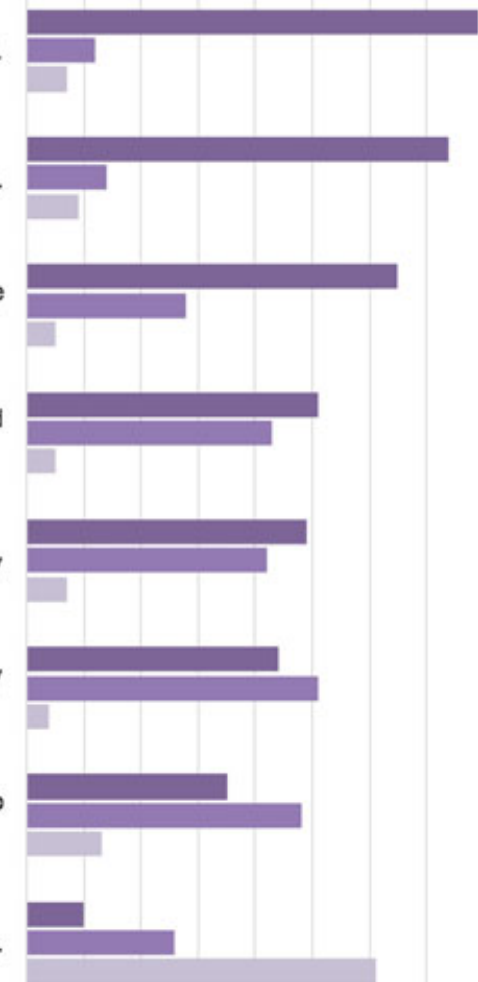

$10 \% \quad 20 \% 30 \% 40 \% 50 \% \quad 60 \%$ 70\% $80 \% 90 \% 100 \%$

\section{= MORE serious than price fixing $=$ About the Same $=$ LESS serious than price fixing}

Figure 6: Comparison with other crime and wrongdoing (average across the four countries). [Colour figure can be viewed at wileyonlinelibrary.com]

poor. ${ }^{108}$ One might suggest that these results would be different if there were greater public awareness of the extent of cartel harm.

\section{CONCLUSION}

This paper fills an important gap in the literature on cartel criminalisation by providing cross-jurisdictional empirical evidence on how consumers expect sellers of goods and services to have calculated their prices, and the extent to which ordinary members of the

108. CMA UK Businesses' Understanding of Competition Law, report prepared for CMA by IFF Research (26 March 2015), available at https://www.gov.uk/government/uploads/system/ uploads/attachment_data/file/429876/UK_businesses_understanding_of_competition_law__report.pdf (accessed 20 December 2016). 
public feel that price fixing is objectionable. Its findings suggest that there is empirical backing for the normative justifications for cartel criminalisation, without the need to rely solely on harm and deterrence arguments. In particular, there is a clear expectation among ordinary members of the public that competing businesses calculate their prices independently of each other. Therefore, cartel arrangements that allow competing firms to act like monopolists go against what is generally expected by citizens in a free market economy. It follows that cartels subvert a competitive norm expected of markets, and that consumers will continue to assume that prices are independent unless they are told otherwise.

The survey results strengthen each of the normative arguments for cartel criminalisation. Under Harding and Joshua's 'spiral of delinquency', clandestine cartel arrangements are not only objectionable because they constitute deliberate, hidden rule breaking. They are also a hidden divergence from what is expected by consumers in the market. This aspect of the findings also fits in with arguments made by MacCulloch and by Beaton-Wells and Fisse, about the subversion of competition and the way in which cartels deny the marketplace the legitimate expectation of a competitive process. However, it is Wardhaugh and Whelan's arguments that are to a significant extent vindicated by these results.

The fact that ordinary members of the public value the competitive process and understand that cartel arrangements will result in higher prices supports Wardhaugh's characterisation of cartels as undermining an important social institution. The results are consistent with the idea that competition amounts to a 'social rule governing distributive justice', especially as the popular understanding of collusive practices is condemnatory despite some confusion as to whether cartels are actually illegal. The expectation that markets are competitive and the implication that they are therefore valued by society also provides a basis for Whelan's retribution-based criminalisation argument, relating to deception. Even in a situation where competitors are silent as to the existence of a cartel arrangement, the fact that most consumers will continue to wrongly assume that prices are competitive may amount to a deception. Where the cartel makes explicit misrepresentations to customers (eg customers are told that prices are increasing because of costs, or where a rigged bid is submitted in a tender process), the moral offensiveness of the conduct is simply heightened. The absence of these aggravating factors does not make their behaviour neutral or absolve them of moral culpability.

The study therefore goes some way in helping to establish what is morally reprehensible about cartel conduct. Combined with the very significant social harm caused by cartels (which is generally not disputed), this may provide a sound justification for labelling cartel conduct as crime. Yet, the results and normative arguments presented above do not defeat the critics of cartel criminalisation completely. In particular, the comparatively weak attitudes and poor levels of awareness of the law in the US, despite it being the oldest and most active criminal cartel enforcement regime in the world, suggest that criminal offences may indeed be ineffective at pulling themselves up by 'their own bootstraps'. In addition, when asked to compare price fixing to other forms of wrongdoing, while many viewed it as comparable to other more established forms of wrongdoing, for many it was less objectionable. The relatively weak support for the imprisonment of individuals is also significant here, although in the UK that appears to have increased significantly since 2007. The weak level of support for imprisonment is also problematic because the sanctions that do enjoy strong public support (corporate fines, individual fines, private damages and director disqualifications) can be administered effectively through a purely civil enforcement 
regime. Only deterrence arguments can counter this point, highlighting how the threat of sanctions other than imprisonment are of limited effectiveness. ${ }^{109}$

Critics such as Williams also suggest that successfully drawing parallels between cartel conduct and more established criminal offences 'does not provide sufficient justification for criminalisation'. ${ }^{110}$ For them, the sanctity of criminal law demands that many categories of corporate wrongdoing be dealt with under civil law only. In reality, neither the criminal or civil law categories are entirely satisfactory - indeed, one could question whether there is a well-delineated notion of what 'criminalisation' actually means or the criteria against which it is judged. ${ }^{111}$ In Europe, competition law enforcement is unmistakably punitive in nature, yet competition authorities have the power to directly impose very significant penalties that are administrative only in name. By contrast, the US has been successfully pressing on with its high level of criminal cartel enforcement, more than a century after it was originally introduced, despite popular perceptions of cartel conduct that are actually weaker than in Europe. Indeed, it appears that Baker may have been mistaken when he noted, "what seems to distinguish the US is public willingness - almost without debate - to treat individuals who participate in cartels as serious criminals who should be treated in the same way as embezzlers, stock swindlers and other economic thieves'. ${ }^{112}$

Nevertheless, the results make it harder to argue that cartel conduct is morally ambiguous or neutral. The study shows that most ordinary members of the public feel that price fixing is serious enough to deserve punitive sanctions of some sort. Moreover, the apparently weak educative effect of enforcement, combined with the fact that respondents were not told how cartels are treated in law, makes the findings all the more significant. Overall, the results were surprisingly similar across the four jurisdictions despite big differences in enforcement and culture. This may suggest that the views captured in the study were primarily informed by a sense of fairness derived from citizens' experiences as consumers and from personal judgements about what is right and wrong.

The fact that, on average, price fixing is viewed as being less serious than other types of corporate wrongdoing may simply reflect a natural tendency for respondents to place greater importance on the categories of wrongdoing with which they are more familiar. In fact, research shows how public perceptions of crime are skewed by media reporting and its preoccupation with certain types of offences. ${ }^{113}$ Indeed, one might suggest that public perceptions of cartels are capable of significantly greater moral opprobrium, if there was better education about these practices.

109. Corporate fines and damages largely impact shareholders, and individual fines or director disqualification can either be indemnified or circumvented through inventive employment arrangements. The reputational damage caused by civil enforcement may also be very limited. This is because many cartels are organised by upstream firms that sell to other businesses and because the very characteristics that make the cartel possible (few competitors and no substitutes to the product in question) mean that customers have no choice but to continue purchasing the product: see Whelan, above $\mathrm{n} 33$, pp 75-78.

110. Williams, above $\mathrm{n} 58, \mathrm{p} 301$, citing J Feinberg Harmless Wrongdoing: The Moral Limits of the Criminal Law (Oxford: Oxford University Press, 1988) vol 4, p 176.

111. Lacey, above n 34, p 942.

112. Baker, above n 11, p 27.

113. R Reiner 'Media made criminality: the representation of crime in the mass media' in $\mathrm{R}$ Reiner, M Maguire and R Morgan (eds) The Oxford Handbook of Criminology (Oxford: Oxford University Press, 2002) pp 302-340. 
While the findings of this paper further the normative justifications for cartel criminalisation, they are unlikely to convince those concerned about 'overcriminalisation'. In particular, they may not provide an entirely satisfactory response to the question of what distinguishes cartel conduct as deserving of criminal liability, as compared to other forms of anti-competitive behaviour. Within the context of cartels, the UK approach of defining criminal liability around an absence of 'openness' is consistent with the results of this paper and the normative justifications to which they relate. Openness also helps to distinguish other forms of competition harm, such as abuse of dominance (by firms with high market power) and attempts at anti-competitive mergers, which are generally observable in a way that concealed cartel conduct is not.

The findings and arguments contained in this paper have helped strengthen the normative basis for criminal sanctions against cartels. Coupled with the level of social harm caused by them and the deterrence arguments, there exists a very sound justification for countries wishing to criminalise their cartel laws. However, these need to be complemented by public awareness and educational programmes, so that the full extent and nature of cartel harm is better understood. There is a clear movement towards cartel criminalisation globally and the main obstacles are not the lack of normative justifications, but the various practical, institutional and procedural challenges surrounding the use of criminal sanctions in competition law, which are not explored in this paper. ${ }^{114}$ The success of cartel criminalisation will ultimately depend more on how well these challenges can be overcome than on the question of moral justification. The continued growth of criminal law in regulating the behaviour of the individual and the firm shows little sign of receding.

114. See eg A Stephan 'Four key challenges to the successful criminalisation of cartel laws' (2014) 2(2) J Antitrust Enforcement 305-332. 